DOI https://doi.org/10.30525/978-9934-26-042-1-40

\title{
ТЕНДЕНЦІЯ ДО ОЛЮДНЕННЯ В СУЧАСНІЙ ЖУРНАЛІСТИЦІ
}

\author{
Сащук T. I. \\ кандидат наук із соиіальних комунікаиій, \\ асистент кафедри соціальних комунікацій \\ Інститут журналістики Київського національного університету \\ імені Тараса Шевченка \\ м. Київ, Украӥна
}

На сьогодні в журналістиці все частіше 3'являється поняття «олюднення» як синонім до запозиченого поняття «персоноцентричність». Ця тенденція акцентувати увагу на особистості, за словами дослідниці Е. Бурдіної, прийшла в телевізійну журналістику ще в 1980-х pp. ХX ст. разом 3 поняттям «інфотейнмент» [1, с. 82]. Спробуємо простежити семантичне наповнення цих двох близьких понять - «олюднення» чи «персоноцентричність» - у наукових розвідках дослідників із соціальних комунікацій, написаних на початку XXI ст.

Як вдалося 3'ясувати, поняття «олюднення» в галузі соціальних комунікацій використовується досить давно, хоча й має різне семантичне наповнення. Так, ще в листопаді 2004 року на сайті асоціації журналістів «Новомедіа» були опубліковані теоретичні зауваги щодо жанрів телевізійної журналістики, в яких було подане таке пояснення щодо телевізійної мови: «Слід пам'ятати відмінність усної мови від писемної. Навіть офіційні («протокольні») матеріали можна «олюднити», зробити не такими казенними, сухими. Для цього уникають довгих речень, що викликають утруднення при усному читанні. Телевізійна лексика не терпить канцеляризмів, професіоналізмів та чисто наукової термінології» [2]. Отже, в цьому контексті поняття «олюднення» означає надання висловлюванням ознак розмовного, живого мовлення.

У 2011 році під час дослідження мовно-стильових особистостей концепту «держава» в творчості Д. Донцова як головного редактора «Літературно-Наукового Вістника» Л. Супрун вдається до процесу персоніфікації цього концепту, що пояснює таким чином: ««Олюднений» зміст концепту «держава» стає ближчим і зрозумілішим читачеві «Літературно-Наукового Вістника»« [8, с. 37]. Потрібно пояснити, що «олюднений концепт «держава»« дослідниця вбачала в таких висловах, як-от: «Держава поборює пацифізм, антимілітаризм, 
сепаратизм; голодує; тицькає вам в руки гроші; калік утримує; звертається до помочі витереблених «кустарів»; хилиться до упадку; розпрягається, розкладається, розпадається; ставляє до кождого з своїх горожан домагання, заклик спільно виконати спільне завдання» [8, с. 37]. Тож справді концепт «держави» набуває рис персоніфікації, про що й зазначає дослідниця Л. Супрун.

Також викликає неабияке зацікавлення той факт, що олюднення $\epsilon$ навіть «типовим прийомом карикатурної стилізації, застосований в інфографіці» [9, с. 95]. При цьому дослідниця Г. Цуканова наводить такий приклад процесу олюднення в цьому значенні - це зображення карти руху потягів метро в м. Лондон у вигляді людського тіла 3 тулубом, кінцівками, венами й артеріями, опорно-руховим апаратом, системами дихання й травлення [9, с. 95]. Тобто в цьому значенні поняття «олюднення» $є$ досить вузьким спеціальним терміном.

2013 року російська дослідниця Т. Сергєєва, аналізуючи функції артжурналістики, відзначила такі характерні риси сучасної журналістики в умовах постмодерністського суспільства: «відбувається відмова від людини (яка відчуває, одухотвореної) як об’єкта журналістики, а разом 3 тим від журналіста-особистості, проте духовна традиція триває (хай і зусиллями невеликого прошарку суспільства)» [292, с. 153]. Тобто вчена наголосила на тому, що духовну традицію все ж таки неможливо, та, власне, й не потрібно знищувати. Тож, на наш погляд, роль особистості і як об'єкта журналістики, і як їі суб'єкта є актуальною і в нинішній час стрімкого розвитку комунікаційних технологій.

2015 року українська дослідниця Е. Бурдіна в межах дослідження інфотейнменту розглянула два близьких поняття - «персоналізація» та «персоніфікація», акцентуючи увагу на їхніх відмінностях: персоналізація стосується особистості автора, а персоніфікація - інших осіб, про які йдеться в журналістському матеріалі [1, с. 80]. При цьому, вчена підкреслила, що в основі кожного з цих понять лежить процес «олюднення» [1, с. 80]. I хоч мова в науковій статті про царину інфотейнменту, проте наведені твердження є дієвими й для інших напрямів журналістики, зокрема для культурної та соціальної.

Насамкінець Е. Бурдіна узагальнила, що персоноцентричність, яка акумулює обидва процеси - i персоналізацію, і персоніфікацію «залишається актуальною і сьогодні, бо в умовах перенасичення інформацією аудиторія віддає перевагу не безликому, невиразному медіапродукту, а унікальному авторському контенту, не сухим фактам та цифрам, а реальним, живим історіям» [1, с. 82]. Та водночас дослідниця застерегла, що «в погоні за яскравими формами подачі та ефективністю донесення повідомлення важливим стає збереження базових засад журналістики» [1, с. 82]. Тобто мова про дотримання 
таких стандартів інформаційної журналістики, як баланс, достовірність, відокремлення фактів від коментарів тощо [6]. Крім того, варто пам'ятати про об'єктивність як один 3 основоположних принципів журналістики, що полягає в такому: це «ретельно відібрані й подані факти, встановлені закономірності їх розвитку; висловлена власна думка журналіста й подана оцінка зображуваного; проведений неупереджений і глибокий аналіз; дотримані достовірність, точність і правдивість висловлення» [5, с. 170]. Отже, називання цього поняття в межах наукових розвідок фахівців із соціальних комунікацій окреслює коло семантичного наповнення поняття «олюднення» та деталізує його.

Для того, щоб мати баланс думок не лише в журналістській практиці, але і в науці про цю практику, яку ми сьогодні зараховуємо до галузі соціальних комунікацій, звернемося до думок журналістів-практиків. Тож нас цікавить питання щодо того, яке ставлення до процесу олюднення 3 двох боків - 3 погляду персоналізації, що стосується саме автора журналістського матеріалу, та 3 погляду персоніфікації, що торкається героїв цих матеріалів та історій про них - висловлюють журналісти, які працюють в різних журналістських напрямах.

В інтерв'ю, датованому 2016 роком, автор та ведучий політичної програми «Прямим текстом» О. Дроздов згадав про процес олюднення в досить несподіваному гендерно маркованому контексті: «Жіночий характер українська журналістика мала б тоді, якби вона зробила серйозний крен від смакування політичних подій до олюднення, більше уваги приділяла людям, емоціям замість сухих коментарів» [7]. Попри поділ олюднення на дві категорії, в цьому інтерв'ю йдеться про персоніфікацію журналістських матеріалів, тобто висвітлення подій і явищ через призму людини, зокрема за допомогою людських історій.

У травні 2017 року на той час журналістка ВВС М. Шокало в інтерв’ю газеті «День» 3 приводу процесу олюднення в ії професійній сфері висловила таку думку: «На сьогодні провідними трендами у світі медіа я вважаю олюднення, персоніфікацію журналістики - людські історії виходять на перший план» [4]. Привертає увагу те, що медійниця, по-перше, олюднення та персоніфікацію назвала провідними світовими тенденціями, по-друге, що назвала їх поруч, що свідчить про їх семантичну близькість, але не тотожність, на чому й наголошувалося в науковій статті харківської дослідниці Е. Бурдіної.

У серпні 2020 року житомирським журналістам було поставлено таке запитання: «Чи замислювались ви над тим, чому люди обирають журналістику професійною сферою, чого чекають від неї у майбутньому?» Серед кількох думок опитаних медійників привертає увагу відповідь журналістки видання «Лесин край» Л. Гудзь, яка так відповідає на питання: «Це сенс мого життя, бо за журналістикою 168 
стоїть Людина. Якщо, звичайно, це справжня журналістика, а не марафон за сенсаціями та скандалами. Саме за можливість писати для людей і про людей і люблю свою роботу... Чекаю від професії, хоч мабуть це наївно, але... Справедливості, об'єктивності, глибини, олюдненості; повернення до журналістики, яка дійсно йде за потребами читача, а не навпаки. I неухильного дотримання морального Кодексу українського журналіста» [3].

Отже, тенденцію до олюдненості в українській журналістиці спостерігаємо лише впродовж останніх п'яти років, тобто десь від 2016-2017 pp. Звісно, поняття «олюднення» в наукових розвідках фахівців із соціальних комунікацій траплялося й раніше, проте мало інше семантичне наповнення, зокрема: олюднена мова, тобто не суха, не казенна, а жива, розмовна («Новомедіа»); олюднений концепт, тобто персоніфікований (Л. Супрун), як прийом карикатурної стилізації (Г. Цуканова), у значенні одухотворення в руслі духовної традиції (Т. Сергєєва), як персоноцентричність, в межах якої виділяються два взаємодоповнювальних процеси - персоналізацію та персоніфікацію (Е. Бурдіна). Варто відзначити, що тенденція до олюдненої журналістики $\epsilon$ досить свіжою й простежується лише впродовж останніх років.

\section{Література:}

1. Бурдіна Е.О. Персоналізація та персоніфікація як ознаки інфотейнменту: розмежування понять. Вісник Харківського національного університету імені В.Н. Каразіна. Серія: Соціальні комунікамії. 2015. Вип. 7-8. С. 79-83.

2. Жанри телевізійної журналістики. 4.11.2004. URL.: https://novomedia.ua/без категоріi//zhanri-televizijnoi-publicistiki.

3. Жур I. «Журналістика - це...» 08.06.2020. URL.: http://www.zhytomyr.travel/zhurnalistika-ce.

4. Клімова О. «Журналісти забувають, що точність для новин, $\epsilon$ найважливішою». 16.05.2017. URL.: https://medialab.online/news/ zhurnalisty-zabuvayut-shho-tochnist-osobly-vo-dlya-novy-n-ye-najvazhlyvishoyu.

5. Пономаренко Л.Г. Принцип об'єктивності в журналістиці: сфера ідеального чи реального? Освіта регіону: політологія, соиіологія, комунікаиіï. 2011. № 3. С. 166-170.

6. Професійні стандарти інформаційної журналістики. 07.10.2016. URL.: https://imi.org.ua/monitorings/profesiyni-standarti-informatsiynojijurnalistiki-i28419.

7. Скуба В. «Від смакування політики до олюднення». 04.03.2011. URL.: https://m.day.kyiv.ua/uk/article/media/vid-smakuvannya-politikido-olyudnennya. 
8. Супрун Л. Концепт «держава» як ключовий у мовній ментальності Д. Донцова-вісниківця. Образ. 2011. Вип. № 12. С. 30-42.

9. Цуканова Г. Карикатурна стилізація інформаційної графіки. Наукові записки Інституту журналістики. 2012. Том. 48. Липень вересень. С. 92-97.

DOI https://doi.org/10.30525/978-9934-26-042-1-41

\title{
ПРОМОЦІЯ УКРАЇНИ В СВІТІ ЧЕРЕЗ ЦИФРОВІ МЕДІА
}

\author{
Широкова I. A. \\ студентка магістратури \\ Інститут журналістики Київського університету \\ імені Бориса Грінченка \\ м. Київ, Україна
}

Оцифрування є актуальною темою не лише для українських, а й для міжнародних медіа. Зокрема у контексті змін, які відбулися у всьому світі через поширення вірусу COVID-19, постає необхідність поширювати інформацію про Україну в цифровому форматі.

Тенденції поступового переходу друкованих медіа у цифровий формат, а також особливості цифрового формату медіа у контексті різних видів людської діяльності вивчали та аналізували такі дослідники: Стратонова Н.О. [2], Манович Л.3. [3], Бодрухіна Т.А. i Манич Н.Є. [1] та інші.

Цифровий формат відкриває переваги, яких раніше не було у друкованих медіа. Одним 3 головних критеріїв $\epsilon$ його гнучкість [3, с. 49], що дає можливість постійно оновлювати інформацію відповідно до поточних змін та потреб. Таким чином, завдяки цифровій промоції подаватиметься лише актуальна інформація, яка швидко поширюватиметься серед іноземної аудиторії.

В Україні цифрова промоція була реалізована й на державному рівні, вона знайшла своє відображення у вповадженій ініціативі «Концепції розвитку цифрової економіки та суспільства України на 2018-2020 роки».

Набуло поширення практики використання владними інституціями можливостей цифрового простору: запуск інформаційних роликів, як на День Незалежності України у 2020 році, який був створений під офіційним брендом нашої держави - «Ukraine Now». Аналогічні кроки 170 